\title{
PENINGKATAN KEMANDIRIAN DAN HASIL BELAJAR MAHASISWA PENDIDIKAN MATEMATIKA DENGAN LESSON STUDY MELALUI BLENDED LEARNING
}

\section{THE APPLICATION OF LESSON STUDY THROUGH BLENDEDThETHODS TO IMPROVE INDEPENDENCE AND LEARNING OUTCOMES OF MATHEMATICS EDUCATION STUDENTS}

\author{
Baidowi, Ketut Sarjana, Dwi Novitasari' dan Eka Kurniawan* \\ Program Studi Pendidikan Matematika, FKIP, Universitas Mataram, Mataram, Indonesia \\ *Email: ekakurniawan2892@unram.ac.id
}

Diterima: 9 Desember 2020. Disetujui: 20 Mei 2021. Dipublikasikan: 2 Juni 2021

\begin{abstract}
Abstrak Penelitian ini bertujuan untuk meningkatkan kemandirian belajar mahasiswa dengan mengkonstruksi kemampuan yang mereka miliki sendiri yang akan berdampak pada peningkatan hasil belajar mahasiswa dengan lesson study melalui blended learning pada mata kuliah Kapita Selekta Matematika. Desain penelitian ini adalah penelitian tindakan kelas Hopskins dengan model lesson study yang bertujuan untuk meningkatkan kemandirian dan hasil belajar mahasiswa dengan lesson study melalui blended learning Penelitian ini akan dilaksanakan di FKIP Universitas Mataram dengan subjeknya adalah mahasiswa pendidikan matematika semester III yang mengambil mata kuliah Kapita Selekta Matematika. Pada penelitian ini perlakuan pada siklus I adalah a). Pembentukan kelompok secara heterogen; b) memberikan motivasi di awal pertemuan c) Melakukan persentasi berbasis online melalui Google Meet d). Sesi diskusi; e) Penguatan oleh dosen model; f) memberikan evaluasi dan pengisian angket untuk mengukur kemandirian belajar. Untuk siklus II tidak jauh beda dengan siklus I, pada siklus II diawal pertemuan memberikan pengutan pada materi prasyarat. Sedangkang untuk siklus III hampir sama dengan siklus II, yang membedakan hanya pada tahap sesi diskusi dirancang lebih menarik lagi berupa sebuah permainan. Sehingga didapatkan hasil kemandirian belajar mahasiswa meningkat di siklus III sebesar 4,43\% dibandingkan pada siklus I sedangkan hasil belajar yang diperoleh mahasiswa meningkat 8,44 poin dari 70,63 pada siklus I menjadi 79,07 pada siklus III. Dari hasil penelitian yang telah dilakukan, dapat disimpulkan bahwa penerapan lesson study melalui blended learning berhasil meningkatkan kemandirian dan hasil belajar mahasiswa.
\end{abstract}

Kata Kunci: Kemandirian Belajar, Lesson Study, Blended Learning

\begin{abstract}
This study aims to increase students' independence and learning outcomes by implementing lesson study through blended learning methods. Students will be taught to construct their own abilities. Furthermore, this will have an impact on improving student learning outcomes. This research approach is action research Hopskins with a lesson study model that aims to increase students' independence and learning outcomes with lesson study through blended learning. The subjects of this study were third-year students from the Mathematics Education Study Program, Faculty of Teacher Training and Education, Universitas Mataram, who took the Capita Selekta Mathematics course. In this study, the treatments in the first cycle were a) heterogeneous group formatioHopkinsovide motivation at the beginning of the meeting; c) conduct online-based presentations through Google Meet; d) discussion sessions; e) strengthening by model lecturers; and f) provide evaluation and filling out a questionnaire to measure learning independence. The second cycle is not much different from the first cycle. In the second cycle, the model lecturer provides guidance on the prerequisite material at the beginning of the meeting. Whereas the third cycle is almost the same as the second cycle, the only difference is that the discussion session is more attractive by implementing a game. The result of the implementation of lesson study through blended learning methods was a) student learning independence increased in the third cycle by $4.43 \%$ compared to the first cycle, and b) learning outcomes obtained by students increased by 8.44 points from 70.63 in the first cycle to 79.07 in the third cycle. From the research results, it can be concluded that the application of lesson study through blended learning methods has been successful in increasing student independence and learning outcomes.
\end{abstract}

Keywords: Independent Learning, Lesson Study, Blended Learning

\section{PENDAHULUAN}

Permasalahan yang seringkali dijumpai dalam pembelajaran matematika salah satunya berkaitan dengan kurangnya kemandirian belajar.Observasi yang dilakukan selama pembelajaran pada matakuliah matematika dasar dan kapita selekta matematika Prodi Pendidikan
Matematika FKIP Universitas Mataram, menunjukkan bahwa terdapat beberapa mahasiswa yang telah mempersiapkan diri dengan membaca dan mempelajari materi yang akan dipelajari sebelum materi tersebut diajarkan sedangkan mahasiswa lainnya hanya menunggu penjelasan dari dosen pengampu mata kuliah. Apabila 
diberikan pertanyaan atau diminta untuk bertanya, sebagian besar mahasiswa hanya terdiam dan tampak kebingungan. Kasus ini mengindikasikan bahwa kemandirian belajar mahasiswa masih rendah yang berdampak pada rendahnya perolehan nilai mereka yang dapat dilihat pada Tabel 1 .

Tabel 1. Nilai Matematika Dasar yang diperoleh Mahasiswa

\begin{tabular}{ccc}
\hline Nilai & $\begin{array}{c}\text { Jumlah } \\
\text { Mahasiswa }\end{array}$ & Persentase \\
\hline $\mathrm{A}$ & 26 & $15,66 \%$ \\
$\mathrm{~B}-\mathrm{B}+$ & 64 & $38,55 \%$ \\
$\mathrm{C}-\mathrm{C}+$ & 52 & $31,33 \%$ \\
$\mathrm{D}-\mathrm{D}+$ & 13 & $7,83 \%$ \\
$\mathrm{E}$ & 11 & $6,63 \%$ \\
\hline \multicolumn{3}{r}{ Sumber: Data Prodi Pendidikan } \\
Matematika FKIP Universitas Mataram
\end{tabular}

Tabel 1 menunjukkan bahwa hanya 90 orang mahasiswa dari 166 orang mahasiswa Program Studi Pendidikan Matematika atau 54,22 $\%$ mahasiswa yang memperoleh nilai minimal B sedangkan sisanya sebanyak 45,78\% mahasiswa masih memperoleh nilai dibawah B. Sedangkan, matematika dasar merupakan mata kuliah paling dasar yang berkaitan dengan materi SMA yang seharusnya telah dikuasai oleh mahasiswa agar dapat memahami mata kuliah di semester selanjutnya.

Menghadapai permasalahan tersebut, maka diperlukan pembelajaaran yang salah satunya berfokus pada kemandirian belajar mahasiswa agar mahasiswa terbiasa untuk belajar dan mengkonstruksi pengetahuan secara mandiri sehingga mereka tidak lagi hanya menunggu penjelasan dari dosen saja. Salah satu yang dapat diterapkan adalah pembelajaran belended learning.

Blended learning adalah pembelajaran yang mengintegrasikan pembelajaran tradisional dan elektronik [1]. Maksudnya yaitu pembelajaran yang memadukan antara pembelajaran secara tatap muka dengan pembelajaran secara online. Melalui pembelajaran ini, mahasiswa diberikan fleksibilitas dalam hal tempat dan waktu belajar sehingga mahasiswa yang kesulitan belajar di kelas memiliki waktu lebih banyak dalam belajar dan memahami materi sementara mahasiswa lainnya dapat bekerja secara mandiri pada konten yang memerlukan penalaran [2]. Mahasiswa dapat mengkonstruksi dan memperluas kemampuan serta pemahaman mereka sendiri melalui pembelajaran online sedangkan melalui pembelajaran tatap muka, mahasiswa dan dosen dapat saling berdiskusi terkait dengan kesulitan yang dihadapi mahasiswa yang tidak dapat mereka selesaikan pada saat pembelajaran secara online

Berdasarkan latar belakang yang telah dipaparkan, maka tujuan dari penelitian ini adalah meningkatkan kemandirian belajar mahasiswa dengan mengkonstruksi kemampuan yang mereka miliki sendiri yang akan berdampak pada peningkatan hasil belajar mahasiswa dengan lesson study melalui blended learning pada mata kuliah kapita selekta matematika. Pemilihan pembelajaran blended learning ini mendukung kegiatan pembelajaran daring yang sedang popular digalangkan oleh FKIP Universitas Mataram. Sedangkan kapita selekta matematika dipilih mengingat masih banyak mahasiswa yang memperoleh nilai dibawah B pada mata kuliah matematika dasar makadiprediksi mereka juga akan mengalami permasalahan yang sama pada mata kuliah kapita selekta matematika dikarenakan kedua mata kuliah ini berkaitan sangat erat selain itu juga berdasarkan pengalaman penelitian sebelumnya yang telah peneliti lakukan.

\section{METODE PENELITIAN}

Pendekatan penelitian ini adalah penelitian tindakan dengan model lesson study yang bertujuan untuk meningkatkan kemandirian dan hasil belajar mahasiswa dengan lesson study melalui blended learning.

Desain penelitian tindakan kelas yang digunakan dalam penelitian ini adalah model penelitian Hopskins [3] yang dapat dilihat pada Gambar 3.1:

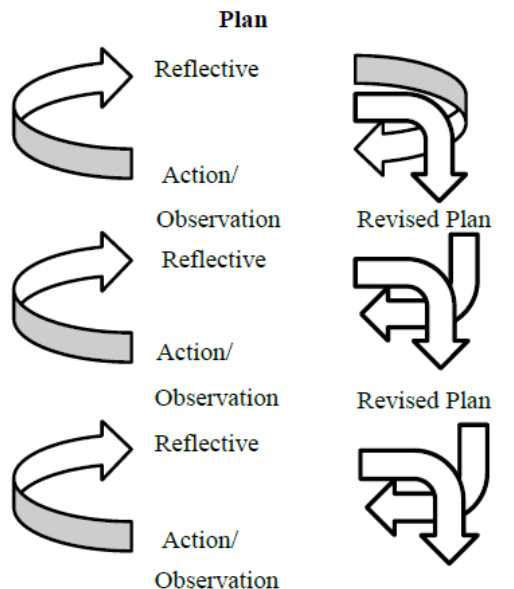

Gambar 1. Spiral Penelitian Tindakan Kelas

Penelitian ini akan dilaksanakan di FKIP Universitas Mataram dengan subjeknya adalah mahasiswa pendidikan matematika semester III yang mengambil mata kuliah Kapita Selekta Matematika. Subjek dalam penelitian ini mengalami beberapa kali siklus pembelajaran yang disesuikan dengan kondisi perencanaan pembelajaran. Penelitian ini direncanakan dilakukan selama dua bulan dengan minimal tiga kali siklus.Kerangka kemandirian dan hasil belajar digunakan mengetahui kelemahan pembelajaran matematika yang dimiliki mahasiswa dan kemajuan yang mereka alami dari awal hingga akhir pembelajaran setelah dilakukan revisi. 
Pada penelitian ini, prosedur dalam memperoleh data adalah dengan dibantu dengan instrument berupa lembar observasi, angket kemandirian belajar, dan tes tertulis. Data yang diperoleh dalam penelitian ini dianalisis secara kuantitatif dan kualitatif menurut karakteristiknya masing-masing. Data diklasifikasikan dan dikategorikan secara sistematik dan menurut karakteristiknya.

Analisis kuantitatif meliputi menentukan skor dari angket kemandirian belajar dan hasil belajar setiap siklus kemudian, melakukan uji analisis inferensial, Uji beda/hipotesis (Uji t) untuk peningkatan kemandirian dan hasil belajar.

Data yang diperoleh dari lembar observasi dan angket kemandirian belajar di analisis dengan cara menghitung persentase dari setiap siklus yang kemudian di katagorikan. Sedangkan untuk hasil belajar melihat rata-rata dari nilai tersebut.

Tablel 2. Katagori Lembar Observasi dan Angket Kemandirian Belajar

\begin{tabular}{cc}
\hline Persentase & Kategori \\
\hline $80 \%<p \leq 100 \%$ & Baik Sekali \\
$60 \%<p \leq 800 \%$ & Baik \\
$40 \%<p \leq 60 \%$ & Cukup \\
$20 \%<p \leq 40 \%$ & Kurang \\
$0 \%<p \leq 20 \%$ & Kurang Sekali \\
\hline
\end{tabular}

Indikator keberhasilan dari penelitian ini adalah tercapainya peningkatan kemandirian dan hasil belajar mahasiswa dimana persentase setiap aspek kemandirianserta persentase rata-rata berkategori baik pada angket kemandirian dan mencapai batas minimal 70\%. Sedangkan, hasil belajar mahasiswa mengalami peningkatan tiap tahapnya dan terjadi peningkatan presentase ketuntasan dalam setiap tahap yang memenuhi standard $\geq 85 \%$

\section{HASIL DAN PEMBAHASAN Analisi Data Kualitatif}

Berdasarkan hasil penelitian selama 3 siklus di dapatkan data kolektif berupa diagram dan table di bawah ini.

Tabel 3. Hasil Penelitian

\begin{tabular}{c|c|c|c}
\hline SIKLUS & $\begin{array}{c}\text { Lembar } \\
\text { Observasi }\end{array}$ & $\begin{array}{c}\text { Angket } \\
\text { Kemandirian } \\
\text { Belajar }\end{array}$ & $\begin{array}{c}\text { Hasil } \\
\text { Belajar }\end{array}$ \\
\hline I & $47,54 \%$ & $78,24 \%$ & 70,63 \\
\hline II & $75,83 \%$ & $81,45 \%$ & 76,10 \\
\hline III & $78,05 \%$ & $82,67 \%$ & 79,07 \\
\hline
\end{tabular}

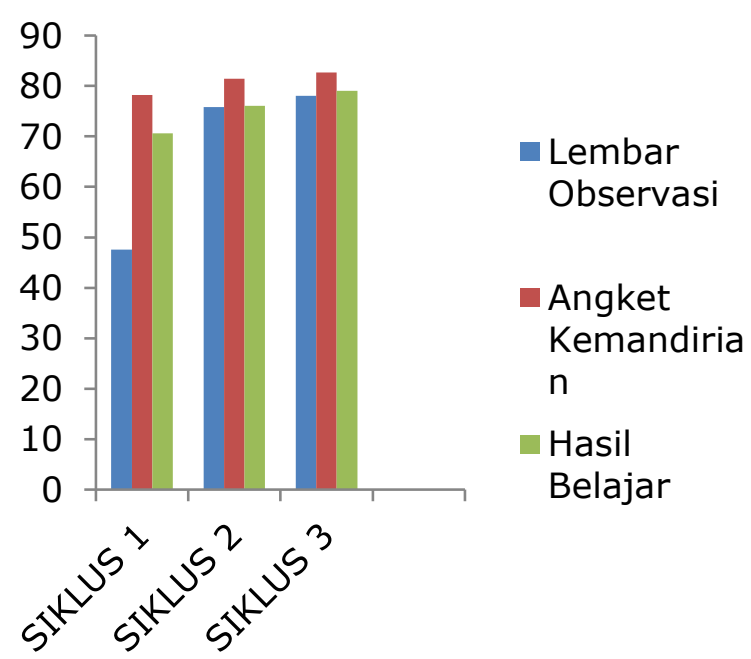

Gambar 2. Hasil Setiap Siklus

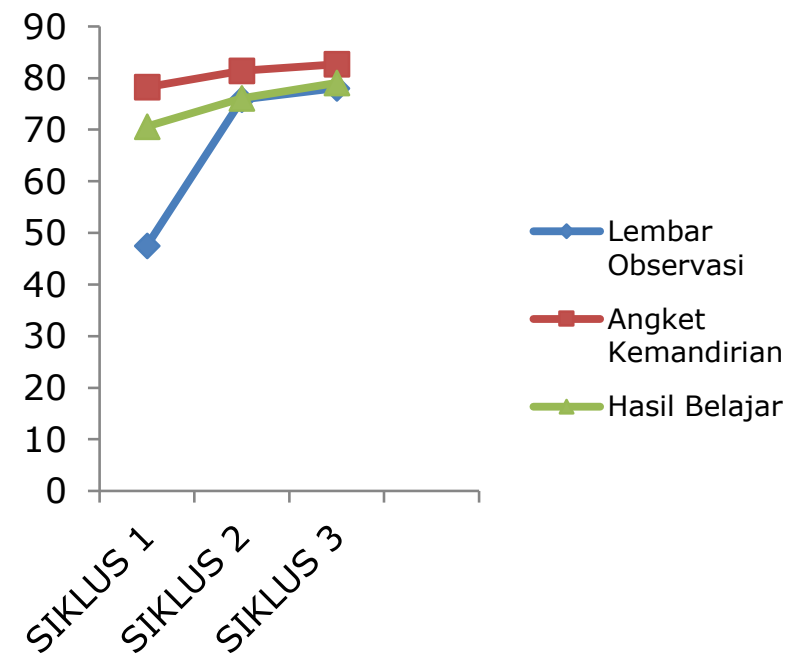

Gambar 3. Hasil Penelitian

Pada diagram 1, diagranm 2 dan table 3 di atas menunjukan hasil peningkatan persentase pada lembar observasi dari setiap siklus. Untuk siklus 1 sebesar 47,54\% berkatagori Cukup. Untuk siklus 2 sebesar $75,83 \%$ berkatagori Baik. Untuk siklus 3 sebesar $78.05 \%$ berkatagori Baik. Sedangkan untuk angket Kemandirian Belajar juga mengalami peningkatan dari setiap siklus. Untuk siklus 1 sebesar 78,24\% berkatagori Baik. Untuk siklus 2 sebesar $81,45 \%$ berkatagori Sangat Baik. Sedankan untuk siklus 3 sebesar $82.67 \%$ berkatagori Sangat Baik. Kemudian yang terakhir untuk rata-rata pada hasil belajar mahasiswa dari setiap siklus juga meningkat. Untuk siklus 1 sebesar 70,63. Untuk siklus 2 sebesar76,10. Sedangkan untuk siklus 3 sebesar 79,07. Adapun pelaksanaan Lesson Studi dapat dipaparkan sebagai berikut:

\section{Siklus 1}

Siklus I dilaksanakan dengan dua kali pertemuan yaitu pada Senin, 28 September 2020 dan 5 Oktober 2020. Alokasi waktu per pertemuan 
adalah 3 x 50 menit. Materi yang disampaikan yaitu mengenai Fungsi dan Persamaan Kuadrat Serta Trigonometri. Rincian tindakan Siklus I dipaparkan secara rinci pada penjelasan berikut.

\section{a. Tahap Plan (Perencanaan)}

Kegiatan perencanaan dimaksudkan untuk mempersiapkan hal- hal yang diperlukan sebelum pelaksanaan tindakan. Rincian kegiatan perencanaan tindakan Siklus I, yaitu 1) Membuat rencana pelaksanaan menggunakan strategi pembelajaran Blended Learning Rancangan penerapan strategi pembelajaran Blended Learning (pembelajaran yang didominasi oleh pembelajaran online dari pada pembelajaran konvensional) dalam penelitian ini adalah a). Pembentukan kelompok secara heterogen; b) memberikan motivasi di awal pertemuan c) Melakukan persentasi berbasis online melalui Google Meet d). Sesi diskusi; e) Penguatan oleh dosen model; f) memberikan evaluasi dan pengisian angket kemandirian belajar.

Pada tahap Perencanaan telah dihasilkan perangkat pembelajaran dan pendukung kegiatan penelitian yang meliputi Rencana Pelaksanaan Pembelajaran Siklus 1, Lembar Observasi Siklus 1, Lembar angket tes Kemandirian Belajar Siklus 1, dan Soal Evaluasi Siklus 1.

\section{b. Tahap (Do) Melaksanakan Perencanaan}

Tindakan Siklus I dilaksanakan sesuai rencana pembelajaran yang telah disusun. Meskipun ada beberapa hal yang tidak dilaksanakan dan berkembang sesuai kondisi kelas, secara keseluruhan pembelajaran berjalan sesuai dengan tahap perencanaan. Rincian pelaksanaan tindakan pada siklus 1 adalah sebagai berikut.

\section{1) Pendahuluan}

Pada tahap ini Dosen mengecek kesiapan mahasiswa dengan mengabsensi mahasiswa dan meminta mahasiswa menyiapkan segala sesuatu yang terkait dengan pembelajaran, selanjutnya Mahasiswa mendengarkan tujuan pembelajaran yang akan dicapai, kemudian dosen memberikan apersepsi dan motivasi dengan melakukan tanya jawab untuk menggali pengetahuan awal mahasiswa yang berkaitan dengan materi yang akan dipelajari.

2) Kegiatan Inti

Dalam Tahap ini mahasiswa melaksakan persentasi melalui Google Meet, selanjutnya dilakukan sesi diskusi bagi mahasiswa yang akan memberikan pertanyaan dan saran terkait dengan substansi materi yang dibahas. Dosen selanjutya memberikan penguatan terkait hasil presentasi dan diskusi mahasiswa. Kemudian mahasiswa diminta untuk mengerjakan soal evaluasi dan mengisi angket kemandirian belajar

3) Penutup

$$
\text { Membimbing Mahasiswa dalam }
$$

menyimpulkan materi yang sudah dibahas dan memberikan penekanan pada hal-hal penting yang perlu diklarifikasi kembali. Terakhir dosen menyampaikan materi yang akan dipelajari pada pertemuan selanjutnya.

c. Tahap (See) refleksi

Tahapan See melihat hasil lembar observasi, angket kemandirian belajar mahasiswa, dan hasil belajar (evaluasi) pada siklus 1 .

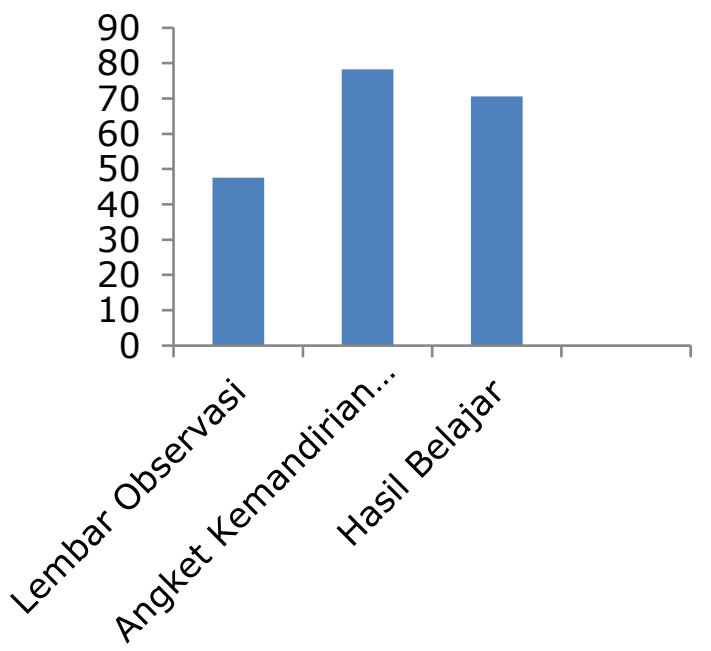

Gambar 4. DataHasil Siklus 1

Gambar 4. menunjukan hasil persentase dan rata-rata pada lembar observasi, angket kemandirian belajar mahasiswa, dan hasil belajar. Untuk lembar observasi sebesar 47,54\% berkatagori Cukup, untukangket kemandirian belajar sebesar 78,24 \% berkatagori Baik, sedangkan untuk hasil belajar menunjukan rata-rata sebesar 70,63. Berdasarkan hasil observasi kegiatan yang dilakukan, terdapat beberapa kelemahan dalam siklus 1 ini, antara lain:

a) Masih lemahnya materi prasyarat dari mahasiswa sehingga perlu di ingatkan kembali pada pertemuan selanjutnya.

b) Waktu yang dibutuhkan melebihi alokasi yang di berikan namun bisa diatasi karena mahasiswa tidak memiliki jadwal kuliah lagi setelah perkuliahan kapita selekta matematika.

c) Dosen kesulitan dalam mengontrol kelas dengan jumlah mahasiswa sebanyak 30 orang, apalagi dengan kondisi kuliah yang dilaksanakan secara daring (google meet).

d) Sesi diskusi yang masih monoton

\section{Siklus 2}

Siklus 2 dilaksanakan berdasarkan hasil refleksi siklus 1 . Siklus 2 dilaksanakan dengan dua kali pertemuan yaitu pada Senin, 12 Oktober 2020 dan 19 Oktober 2020. Alokasi waktu per pertemuan adalah 3 x 50 menit. Materi yang disampaikan yaitu 
mengenai eksponensial dan logaritma serta turunan. Rincian tindakan Siklus 2 dipaparkan secara rinci pada penjelasan berikut.

a. Tahap Plan (Perencanaan)

Pada tahap ini didasari oleh hasil refleksi tahap 1. Kegiatan perencanaan dimaksudkan untuk mempersiapkan hal- hal yang diperlukan sebelum pelaksanaan tindakan. Rincian kegiatan perencanaan tindakan Siklus 2 tidak jauh beda dengan siklus 1, yaitu 1) Membuat rencana pelaksanaan menggunakan strategi pembelajaran Blended Learning. Rancangan penerapan strategi pembelajaran Blended Learning (pembelajaran yang didominasi oleh pembelajaran online dari pada pembelajaran konvensional) dalam penelitian ini adalah a). Pembentukan kelompok secara heterogen, dimana di bagi menjadi dua kelas sehingga perkelas maksimal meiliki siswa sebanyak 15 orang. Pembentukan kelompok atau kelas kecil ini dimaksudkan agar dosen dapat memantau dan mengontrol kelas dengan lebih baik, b) memberikan motivasi di awal pertemuan, c) Memberikan penguatan pada materi prasyarat d) Melakukan persentasi berbasis online melalui Google Meet d). Sesi diskusi dalam bentuk sebuah permainan yang berkaitan dengan absen/NIM mahasiswa; e) Penguatan oleh dosen model dengan menggunakan bantuan aplikasi GeoGebra untuk membantu mahasiswa dalam memvisualisasikan bentuk grafik; f) memberikan evaluasi dan pengisian angket kemandirian belajar.

Pada tahap Perencanaan telah dihasilkan perangkat pembelajaran dan pendukung kegiatan penelitian yang meliputi Rencana Pelaksanaan Pembelajaran Siklus 2, Lembar Observasi Siklus 2, Lembar angket tes Kemandirian Belajar Siklus 2, dan Soal Evaluasi Siklus 2.

\section{b. Tahap (Do) Melaksanakan Perencanaan}

Tindakan Siklus 2 dilaksanakan sesuai rencana pembelajaran yang telah disusun. Rincian pelaksanaan tindakan pada siklus 2 adalah sebagai berikut.

\section{1). Pendahuluan}

Pada tahap ini Dosen mengecek kesiapan mahasiswa dengan mengabsensi mahasiswa dan meminta mahasiswa menyiapkan segala sesuatu yang terkait dengan pembelajaran, Selanjutnya Mahasiswa mendengarkan tujuan pembelajaran yang akan dicapai, kemudian dosen memberikan apersepsi dan motivasi dengan melakukan tanya jawab untuk menggali pengetahuan awal mahasiswa yang berkaitan dengan materi yang akan dipelajari. Dosen memberikan penegasan terkait dengan materi prasyrat pada persentasi kali ini

\section{2). Kegiatan Inti}

Dalam Tahap ini mahasiswa melaksakan persentasi melalui Google Meet, selanjutnya dilakukan sesi diskusi berdasarkan NIM/absen mahasiswa untuk menunjukan bentuk tanggung jawabdan partisipasi mahasiswa. Dosen selanjutya memberikan penguatan terkait hasil presentasi dan diskusi mahasiswa dengan menggunakan bantuan aplikasi Geogebra khususnya dalam memvisualisasikan grafik dari suatu fungsi. Kemudian mahasiswa diminta untuk mengerjakan soal evaluasi dan mengisi angket kemandirian belajar

\section{3). Penutup}

Membimbing Mahasiswa dalam menyimpulkan materi yang sudah dibahas dan Memberikan penekanan pada hal-hal penting yang perlu diklarifikasi kembali. Terakhir dosen Menyampaikan materi yang akan dipelajari pada pertemuan selanjutnya.

\section{c. Tahap (See) refleksi}

Tahapan See melihat hasil lembar observasi, angket kemandirian belajar mahasiswa, dan Hasil belajar (evaluasi) pada siklus 2. Seperti yang ditunjukan pada diagram di bawah.

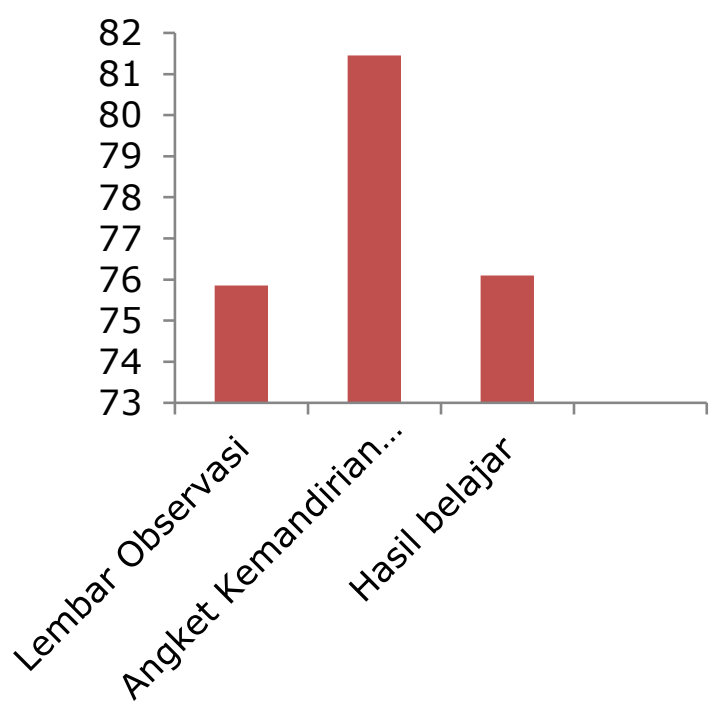

Gambar 5. DataHasil Siklus 2

Gambar 5 menunjukan hasil persentase dan rata-rata pada lembar observasi, angket kemandirian belajar mahasiswa, dan Hasil belajar. Untuk lembar observasi sebesar 75,85\% berkatagori Baik, untuk angket kemandirian belajar sebesar 81,45 \% berkatagori Sangat Baik, sedangklan untuk hasil belajar menunjukan ratarata sebesar 76,10. Berdasarkan hasil observasi, diperoleh beberapa kelemahan dalam siklus 2 ini, antara lain:

a) Karena kelas dibagi menjadi dua kelompok kecil, tiap kelompok mahasiswa yang bertugas harus mempresentasikan materi hasil diskusi kelompoknya sebanyak dua kali pada tiap kelompok kelas yang berbeda. Sehingga dari 
segi waktu, kurang efisien.

b) Mahasiswa dalam kelas yangsatu dan kelas yang lainnya harus bertukar kelas agar mendapatkan pemateri yang berbeda.

c) Hasil diskusi pada tiap kelompok kecil atau materi tambahan yang diperoleh berbeda-beda tergantung dari keaktifan mahasiswa dalam tiap kelompok kecil saat proses diskusi berlangsung.

d) Melibatkan dosen model yang lebih banyak dalam observasi.

\section{Siklus 3}

Siklus dilaksanakan berdasarkan hasil refleksi siklus 2. Siklus 3 dilaksanakan dengan dua kali pertemuan yaitu pada Senin, 26 Oktober dan 02 November 2020. Alokasi waktu per pertemuan adalah 3 x 50 menit. Materi yang disampaikan yaitu mengenai Integral. Rincian tindakan Siklus 3 dipaparkan secara rinci pada penjelasan berikut.

a. Tahap Plan (Perencanaan)

Pada tahap ini didasari oleh hasil refleksi siklus 2. Kegiatan perencanaan dimaksudkan untuk mempersiapkan hal- hal yang diperlukan sebelum pelaksanaan tindakan. Rincian kegiatan perencanaan tindakan Siklus 3 tidak jauh beda dengan siklus 2, yaitu 1) Membuat rencana pelaksanaan menggunakan strategi pembelajaran Blended Learning. Rancangan penerapan strategi pembelajaran Blended Learning (pembelajaran yang didominasi oleh pembelajaran online dari pada pembelajaran konvensional) dalam penelitian ini adalah a). Pembentukan kelompok secara heterogen, dimana kondisi kelas dikembalikan menjadi satu kelas dengan memperbanyak observes dan dosen model tambahan b) memberikan motivasi di awal pertemuan, c) Memberikan penguatan pada materi prasyarat d) Melakukan persentasi berbasis online melalui Google Meet d). Sesi diskusi dalam bentuk sebuah permainan yang berkaitan dengan absen/NIM mahasiswa; e) Penguatan oleh dosen model dengan memanfaatkan aplikasi GeoGebra khususnya dalam memberikan gambaran/visualisasi grafik suatu fungsi dalam penerapan integral dalam menentukan luas maupun volume; f) memberikan evaluasi dan pengisian angket kemandirian belajar.

Pada tahap Perencanaan telah dihasilkan perangkat pembelajaran dan pendukung kegiatan penelitian yang meliputi Rencana Pelaksanaan Pembelajaran Siklus 3, Lembar Observasi Siklus 3, Lembar angket tes Kemandirian Belajar Siklus 3, Soal Evaluasi Siklus 3.

\section{b. Tahap (Do) Melaksanakan Perencanaan}

Tindakan Siklus 3 dilaksanakan sesuai rencana pembelajaran yang telah disusun. Rincian pelaksanaan tindakan pada siklus 3 adalah sebagai berikut.

1). Pendahuluan
Pada tahap ini Dosen mengecek kesiapan mahasiswa dengan mengabsensi mahasiswa dan meminta mahasiswa menyiapkan segala sesuatu yang terkait dengan pembelajaran, Selanjutnya mahasiswa mendengarkan tujuan pembelajaran yang akan dicapai, kemudian dosen memberikan apersepsi dan motivasi dengan melakukan tanya jawab untuk menggali pengetahuan awal mahasiswa yang berkaitan dengan materi yang akan dipelajari. Dosen memberikan penegasan terkait dengan materi prasyrat pada persentasi kali ini

2). Kegiatan Inti

Dalam Tahap ini mahasiswa melaksakan persentasi melalui Google Meet, selanjutnya dilakukan sesi diskusi berdasarkan NIM/absen mahasiswa yang disebutkan untuk menunjukan bentuk tanggung jawab dan partisipasi mahasiswa. Dosen selanjutya memberikan penguatan terkait hasil presentasi dan diskusi mahasiswa dengan menggunakan bantuan aplikasi GeoGebra. Kemudian mahasiswa diminta untuk mengerjakan soal evaluasi dan mengisi angket kemandirian belajar

3). Penutup

Membimbing Mahasiswa dalam menyimpulkan materi yang sudah dibahas dan Memberikan penekanan pada hal-hal penting yang perlu diklarifikasi kembali. Terakhir dosen Menyampaikan materi yang akan dipelajari pada pertemuan selanjutnya.

c. Tahap (See) refleksi

Tahapan See melihat hasil lembar observasi, angket kemandirian belajar mahasiswa, dan Hasil belajar (evaluasi) pada siklus 3. Seperti yang ditunjukan pada diagram di bawah.

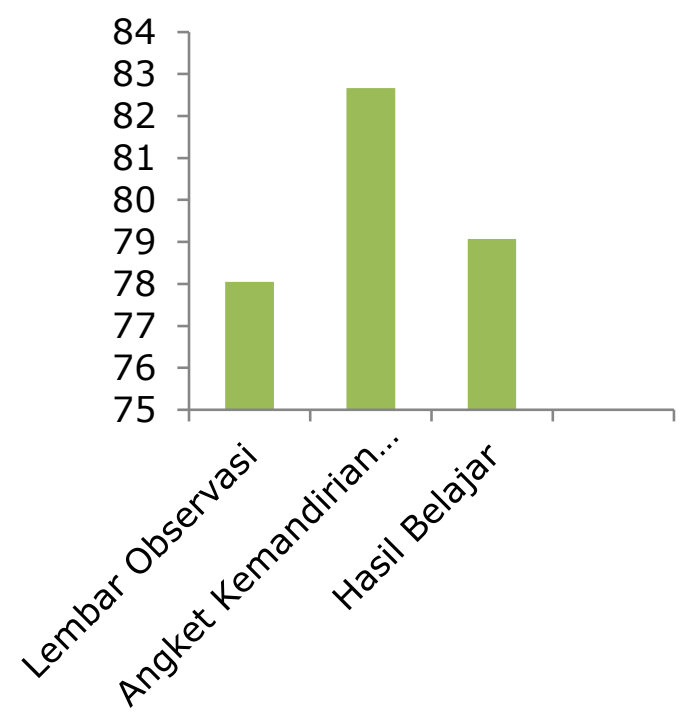

Gambar 6. DataHasil Siklus 3

Gambar 6 menunjukan hasil persentase dan rata-rata pada lembar observasi, angket kemandirian belajar mahasiswa, dan Hasil belajar. 
Untuk lembar observasi sebesar 78,05 \% berkatagori Baik, untuk angket kemandirian belajar sebesar 82,67 \% berkatagori Sangat Baik, sedangklan untuk hasil belajar menunjukan ratarata sebesar 79,06

\section{Analisis Data Kuantitatif}

Data berdistribusi normal dan homogen serta jumlah sampelnya sama, maka uji beda (uji t) yang digunakan adalah Polled Varians. Berdasarkan hasil perhitungan, didapat T-hitung= 2,09, sedangkan $\mathrm{T}$-tabel $=1,978$ pada taraf signifikansi $\alpha=5 \%$ dengan derajat kebebasan (df) = 72. Harga T-hitung lebih besar dari T-tabel, dan lebih besar dari -ttabelmaka $\mathrm{H} 0$ ditolak dan $\mathrm{Ha}$ diterima. Jadi, dapat disimpulkan bahwa terdapat peningktan yang signifikan antara hasil belajar siswa disetiap siklus.

Sedangkan untuk kemandirian Belajar didapat $\mathrm{T}$-hitung $=2,447$, sedangkan $\mathrm{T}$-tabel $=$ 0,016 pada taraf signifikansi $\alpha=5 \%$ dengan derajat kebebasan $(\mathrm{df})=98$. Harga T-hitung lebih besar dari T-tabel, dan lebih besar dari -ttabelmaka H0 ditolak dan Ha diterima. Jadi, dapat disimpulkan bahwa terdapat peningktan yang signifikan antara kemandirian Belajar siswa disetiap siklus.

Tinjauan sistematis dan analisis data dilakukan untuk menyelidiki peningkatan kemandirian dan hasil belajar mahasiswa pendidikan matematika dengan lesson study melalui blended learning. Hasil penelitian menunjukkan blended learning menumbuhkan keterpusatan pada mahasiswa, mendorong keterlibatan mahasiswa yang tinggi dan memfasilitasi proses bagi mahasiswa untuk membangun pengetahuan mereka sendiri yang mana hal ini akan berpengaruh terhadap kemandirian belajar mahasiswa yang pada akhirnya akan berdampak positif pula terhadap hasil belajar mahasiswa[4]. Hal ini dapat dilihat dari peningkatan kemandirian belajar mahasiswa di siklus III sebesar 4,43\% dibandingkan pada siklus I sedangkan hasil belajar yang diperoleh mahasiswa meningkat 8,44 poin dari 70,63 pada siklus I menjadi 79,07 pada siklus III. Penelitian sebelumnya yang mendukung temuan dalam penelitian ini adalah penelitian yang dilakukan [5]

Untuk meningkatkan kemandirian dan hasil belajar mahasiswa dengan lesson study melalui blended learning dapat dilakukan dengan langkah-langkah sebagai berikut:

1. Mahasiswa dibagi secara kelompok untuk berdikusi terkait dengan materi yang telah diberikan.

2. Tiap kelompok mengirimkan hasil diskusinya berupa makalah 1 minggu sebelum tampil. Mahasiswa lainnya membaca dan memahami materi diskusi yang diberikan secara mandiri atau berdiskusi bersama anggota kelompoknya secara online.

3. Pada waktu perkuliahan, kelompok yang bertugas mempresentasikan hasil diskusinya secara online melalui video meeting, dilanjutkan dengan sesi diskusi kelompok.

4. Sesi diskusi berdasarkan NIM/absen mahasiswa yang disebutkan untuk menunjukan bentuk tanggung jawab dan partisipasi mahasiswa yang dikemas dalam bentuk permainan/games.

5. Dosen memberikan penguatan terkait hasil presentasi dan diskusi mahasiswa dengan menggunakan bantuan aplikasi GeoGebra.

Blended learning dengan lesson study memberikan dampak positif dimana pembelajaran secara online menggunakan pembelajaran kooperatif dan diskusi kelompok secara online dengan melibatkan permainan membantu mahasiswa dalam kemandirian belajarnya. Mahasiswa mempersiapkan diri dengan membaca beberapa referensi tambahan sebelum perkuliahan dilaksanakan. Tidak hanya kelompok yang bertugas presentasi saja yang mempersiapkan diri memahami materi akan dipelajari. Terlebih, materi presentasi tiap kelompok telah diberikan beberapa hari sebelumnya sehingga mahasiswa lainnya dapat mempelajarinya terlebih dahulu secara mandiri. Blended learning juga mendorong mahasiswa introvert untuk mengekspresikan diri melalui forum diskusi online Hal ini menjadi salah satu dampak positif bagi peningatan kemadirian belajar mahasiswa ditiap siklusnya [6-8].

Terkait dengan pemahaman mahasiswa terhadap materi yang diberikan, diskusi kelompok dan penguatan yang diberikan oleh dosen pada akhir sesi diskusi dan penggunaan aplikasi Geo Gebra dalam proses pembelajaran pula sangat membantu mahasiswa [9].

\section{KESIMPULAN}

Berdasarkan hasil penelitian, dapat disimpulkan bahwa kemandirian dan hasil belajar mahasiswa III/C pada mata kuliah Kapita Selekta Matematika mengalami peningkatan. Pembelajaran dengan lesson study melalui blended learning merupakan salah satu upaya efektik dalam menanamkan kemandirian belajar mahasiswa program studi pendidikan matematika yang mengikuti mata kuliah kapita selekta matematika.

\section{UCAPAN TERIMA KASIH}

Kami atas nama penulis mengucapkan terimakasih yang sebesar-besarnya kepada Universitas Mataram atas dukungan materi melalaui Penelitian BNPB.

\section{DAFTAR REFRENSI}

[1] Yaghmour, K. S. (2016). Effectiveness of Blended Teaching Strategy on the Achievement of Third Grade Students in 
Mathematics. Journal of Education and Practice, 7(5), 65-73.

[2] Özüdoğru, M., \& Aksu, M. (2020). Pre-service Teachers 'Achievement and Perceptions of The Classroom Environment in Flipped Learning and Traditional Instruction Classes. Australasian Journal of Educational Technology, 36(4), 27-43. https://doi.org/https://doi.org/10.14742/ajet.51 15

[3] Arikunto, dkk. (2006). Penelitian Tindakan Kelas. Jakarta: PT. Bumi Aksara

[4] Sudianto, Dwijanto, \& Dewi, N. A. (2019). Students' Creative Thinking Abilities and Self Regulated Learning on Project-Based Learning with LMS Moodle. Unnes Journal of Mathematics Education Research, 8(1), 10-17.

[5] Atmacasoy, A., \& Aksu, M. (2018). Blended Learning at Pre-Service Teacher Education in Turkey: A Systematic Review. Educ Inf Technol, 23, 2399-2422. https://doi.org/https://doi.org/10.1007/s10639018-9723-5

[6] Perrow, M. (2017). Strengthening the conversation in blended and face-to face courses: Connecting online and in-person learning with crossover protocols. College Teaching, 65(3), 97-105. https://doi.org/10.1080/87567555.2017.130086 9

[7] Ilhamdi, M. L., \& Mertha, I. G. (2020). Penerapan Model Pembelajaran Kooperatif Tipe Investigasi Kelompok Dalam Pembelajaran Biologi Umum. Jurnal Pijar Mipa, 15(1), 20-26.

[8] Ilhamdi, M. L., Al Idrus, A., \& Santoso, D. (2021). Sikap Belajar Kaitannya dengan Hasil Belajar IPA Siswa Madrasah Tsanawiyah Al Maarif Praya Timur Kabupaten Lombok Tengah. Jurnal Pijar Mipa, 16(1), 129-135.

[9] Tegegne, K. M. (2014). The Influence of ELearning on the Academic Performance of Mathematics Students in Fundamental Concepts of Algebra Course: The Case in Jimma University. Ethiopian Journal of Education and Sciences, 9(2), 41-59.

[10] Seloraji, P., \& Eu, L. K. (2017). Students , Performance in Geometrical Reflection Using GeoGebra. Malaysian Online Journal of Educational Technology, 5(1), 65-77.

[11] Makhrus, M., Nur, M., \& Widodo, W. (2014). Model Perubahan Konseptual dengan
Pendekatan Konflik Kognitif (MPKPKK). Jurnal Pijar MIPA, 9(1).

[12] Ningthias, D. P., Siahaan, J., \& Purwoko, A. A. (2018). Pengaruh Model Quantum Learning Menggunakan Lks Terhadap Hasil Belajar Siswa Kelas Xi Sman 2 Mataram. Jurnal Pijar Mipa, 13(2), 100-105. 